\title{
The Evolving Locus Standi and Causation Requirements in Kenya: A Precautionary Turn for Climate Change Litigation?
}

\begin{abstract}
Lydia A. Omuko-Jung*
A recognised challenge for climate litigation is the fundamental incompatibility between the climate change problem and legal systems' ability to hold critical players accountable. Locus standi and causation are critical stumbling blocks in the quest for climate justice. In Kenya, the requirements for locus standi and causation in public interest environmental litigation have been evolving. This article explores this evolution, showing three ways in which this creates opportunities for climate litigation. Firstly, there is no need to show particularised injury, which allows any person to sue for climate-related actions or inactions. Secondly, liability routes have been created that allow litigants to avoid the restrictive causation requirements, so that the plaintiff would not have to show any injury, let alone link harms to emissions from specific entities or to inaction. Thirdly, the courts take a precautionary approach which then shifts the burden of proof to the defendants, who are required to show that their activities or inaction do not pose a threat of serious or irreversible damage. These recent developments provide the needed legal opportunities for climate litigation and could make Kenya a potential hotspot for future climate change cases.
\end{abstract}

\section{Introduction}

The inherent stochasticity of the climate system, the temporal and geographical scope of anthropogenic climate change and the diffuse nature of greenhouse gas (GHG) emissions create particular challenges for holding governments and private actors liable for their action or inaction relating to climate change. To date locus standi has been a significant hurdle in climate change litigation and, when cases proceed to the merits, causation is expected to be as big of a challenge. ${ }^{1}$ Usually, plaintiffs need to show they have suffered a concrete and particularised injury from an omission or commission, ${ }^{2}$ yet certain events that cause harm may not be attributable to anthropogenic climate change. Under Euro-
DOI: $10.21552 / \mathrm{ccl} / \mathrm{r} / 2021 / 2 / 8$

* Doctoral Researcher, Institute of Public Law and Political Science, University of Graz; Legal Analyst, Climate Change Litigation Initiative; Advocate of the High Court of Kenya. For correspondence: <lydia.omuko@uni-graz.at> This work was funded by the Austrian Science Fund (FWF) under Research Grant W1256 (Doctoral Programme Climate Change: Uncertainties, Thresholds and Coping Strategies). I am grateful to Kim Bouwer and TracyLynn Field for the useful discussions and comments on earlier drafts. I also wish to thank the anonymous reviewers for their insightful comments.

1 Some of the cases that have recently been dismissed for lack of locus standi (among other reasons) are Juliana v United States [2020] No18-36082 (9th Circ); T-330/18 - Armando Carvalho and Others v The European Parliament and the Council [2019] ECLI:EU:T:2019:324; Smith v Fronterra Co-Operative Group Limited [2020] NZHC 419. In Lliuya v RWE AG Essen Regional
Court Case No. 2 O 285/15, the district court dismissed the claim for failure to prove causation. The decision was partly reversed on appeal where the appellate court declared the case admissible and moved to the evidentiary stage to determine the risk to plaintiff's property and the defendant's contribution to the risk. It however remains to be seen whether the plaintiff will prove his case at trial. For a discussion of these issues in climate change litigation, see also Michael Byers, Kelsey Franks and Andrew Gage, 'Internalization of Climate Damages Litigation' (2017) 7 Washington Journal of Environmental Law \& Policy. 264, 278-279; Ian R Curry, 'Establishing Climate Change Standing: A New Approach' (2019) 36 Pace Environmental Law Review 297; Valentina Jacometti, 'Climate Change Litigation: Global Trends and Critical Issues in the Light of the Urgenda 2018 Decision and the IPCC Special Report "Global Warming of $1.5^{\circ} \mathrm{C}^{\prime \prime \prime}$ (2020) 20 Global Jurist; Geetanjali Ganguly, Joana Setzer and Veerle Heyvaert, 'If at First You Don't Succeed: Suing Corporations for Climate Change' (2018) 38 Oxford Journal of Legal Studies 841; 
pean Union law, for instance, persons claiming a public right or interest have to show they suffered an injury greater than other members of the public, ${ }^{3}$ making it difficult to get redress for injuries that are diffuse in nature. Additionally, the diffuse and transboundary character of GHG emissions makes it difficult to attribute liability to particular actors.

Developments in climate science have made it possible to quantify the proportional contribution of large emitters to global emissions and to identify the contribution of anthropogenic climate change to specific events. ${ }^{4}$ However, it still remains difficult for a plaintiff to prove on a balance of probabilities that their injury occurred because of the defendant's influence on the climate. ${ }^{5}$ Climate litigators have sought to deal with this challenge by choosing more incidental cases, ${ }^{6}$ trying new legal strategies, ${ }^{7}$ or relying on recent improved scientific studies that would satisfy the relevant legal tests. ${ }^{8} \mathrm{Nev}$ ertheless, successfully attributing liability for climate change impacts through litigation is an uphill task. Litigants in cases like Juliana $v$ U.S and Comer $v$ Murphy Oil had their claims dismissed despite trying new legal strategies and using improved evidence. ${ }^{9}$ The question is: Can legal systems evolve to consider the intricacies of climate change which makes it difficult to adjudicate climate change is-

Jacqueline Peel, 'Issues in Climate Change Litigation' (2011) 5 Climate Law Review 15.

2 Juliana v U.S (n 1) 18; Lujan v Defenders of Wildlife 504 US 555 (1992) [560].

3 Carvalho v Parliament and Council (n 1) paras 44-48.

4 See for instance Richard Heede, 'Tracing Anthropogenic Carbon Dioxide and Methane Emissions to Fossil Fuel and Cement Producers, 1854-2010' (2014) 122 Climatic Change 229; RF StuartSmith and others, 'Increased Outburst Flood Hazard from Lake Palcacocha Due to Human-Induced Glacier Retreat' (2021) 14 Nature Geoscience 85.

5 This is especially more challenging where the injuries arise from specific extreme events. See Tobias Pfrommer and others, 'Establishing Causation in Climate Litigation: Admissibility and Reliability' (2019) 152 Climatic Change 67, 68; Sabrina McCormick and others, 'Science in Litigation, the Third Branch of U.S. Climate Policy' (2017) 357 Science 979.

6 See Joana Setzer and Rebecca Byrnes, 'Global Trends in Climate Change Litigation: 2020 Snapshot' (Grantham Research Institute on Climate Change and the Environment and Centre for Climate Change Economics and Policy, London School of Economics and Political Science 2020) 6-7.

7 Some of these strategies include invoking the state's duty of care principle as was the case in the Urgenda Foundation $v$ the Kingdom of the Netherlands and the use of the atmospheric trust sues within the traditional causation and locus standi requirements?

One such evolution is happening in Kenya. Over the past four decades, the framework for public interest environmental litigation has advanced rapidly. Previously, public interest matters were litigated by the Attorney General and private individuals could litigate only where they had suffered an injury greater than other members of the public. This has evolved to the current position where individuals can file environmental cases without the need to demonstrate an injury. This article explores the evolution of the locus standi and causation requirements in public interest environmental litigation in Kenya and its potential impacts on climate change litigation.

The concept of public interest environmental litigation began in Kenya in 1980 s with attempts by Nobel Laureate Wangari Maathai to challenge government's decision to allow construction of private property in a public recreational park. ${ }^{10}$ This was met by the restrictive standing requirements and a non-receptive judiciary that was common in public interest litigation. ${ }^{11}$ The enactment of the Environmental Management and Coordination Act of 1999 (EMCA $)^{12}$ introduced the concept of granting standing for environmental protection cases to potentially every person. This was followed by the promulga-

concept in Juliana $v$ U.S (n 1). For a snapshot of these strategies, see Kim Bouwer, 'The Unsexy Future of Climate Change Litigation' (2018) 30 Journal of Environmental Law 483, 489-491.

8 The "Carbon Majors Report," which provides the historical GHC contribution of large emitters, is already contributing to climate litigation. The Lliuya $v$ RWE's claim of $0.47 \%$ of the costs for preventive measures is based on the report's findings of RWE's GHG emissions from 1751 to 2010. The Carbon Majors Report also formed the basis of the Petition in In re Greenpeace Southeast Asia and Others No. CHRNI-2016-0001 (19 September 2019). See Richard Heede, 'Tracing Anthropogenic Carbon Dioxide and Methane Emissions to Fossil Fuel and Cement Producers, 1854-2010' (2014) 122 Climatic Change 229. See also Rupert F Stuart-Smith and others, 'Filling the Evidentiary Gap in Climate Litigation' [2021] Nature Climate Change <http://www .nature.com/articles/s41558-021-01086-7> accessed 28 June 2021. Stuart-Smith et al note that litigants in cases like Bushfire Survivors for Climate Action Inc. v. Environment Protection Authority [2020] NSWLEC 152 have provided stronger and more recent scientific evidence.

9 Juliana v U.S (n 1); Comer et al v Murphy Oil USA et al No 1:11 CV-00220 (SD Miss) (20 March 2012).

10 Wangari Maathai v Kenya Times Media Trust Ltd Civ Case 5403 of 1989 (High court at Nairobi) [1989] eKLR.

11 See part II of this article.

12 No. 8 of 1999. 
tion of the 2010 Kenyan Constitution, which introduced key reforms, including expansive environmental rights and access to justice provisions. The constitutional and EMCA approach in public interest environmental litigation was transposed into the Climate Change Act (CCA), ${ }^{13}$ which specifically provides for enforcement of rights relating to climate change.

Part II of the article discusses the evolution of $l_{0}$ cus standi and causation in three periods marked by key constitutional and legislative changes: the period under the (now repealed) 1969 Constitution, the enactment of the EMCA in 1999 and finally, the period after the promulgation of the current Constitution in 2010. With the understanding that climate cases are litigated within existing legal systems, this part provides an overview of locus standi and causation requirements in environmental and public interest litigation and explains why this liberalised approach was fought for, thereby justifying the argument that these developments are ingrained and durable. Understanding this is necessary to deduce how climate cases are likely to be handled, not only because Kenya will probably see more climate litigation in future, but also because it is likely that climate change arguments will increasingly be introduced as secondary issues in disputes about environmental pollution or natural resources more general-

13 No. 11 of 2016.

14 Jacqueline Peel and Jolene Lin, 'Transnational Climate Litigation: The Contribution of the Global South' (2019) 113 American Journal of International Law 679, 716-717.

15 See ibid 695; United Nations Environment Programme, Global Climate Litigation Report: 2020 Status Review (2020) 7 <https:// www.unenvironment.org/resources/report/global-climate -litigation-report-2020-status-review> accessed 18 May 2021. Setzer and Byrnes ( $\mathrm{n} 6$ ).

16 For an analysis of the grounds for climate change litigation in Kenya, see Lydia A Omuko-Jung, 'Climate Change Litigation in Kenya: Possibilities and Potentiality' in Francesco Sindico and Makane Moise Mbegue (eds), Comparative Climate Change Litigation: Beyond the Usual Suspects, vol 47 (1st edn, Springer International Publishing 2021).

17 Anyango and Odaga for instance highlight the importance of a litigation strategy that combines climate change issues with other available legal channels and approaches. See Eva Maria Anyango and Mark Odaga, 'Leveraging Existing Approaches and Tools to Secure Climate Justice in Africa' Carbon \& Climate Law Review, at 129 of this edition.

18 It is also important to note that Section 23(3) of the CCA is drafted in a similar way as Article 70 (3) of the Constitution and Section 3(3) EMCA. Courts are therefore likely to interpret the CCA provision in a similar manner as the constitutional and EMCA provision. ly. ${ }^{14}$ The part concludes with an analysis of the CCA, where the liberalised attitude on locus standi and causation from the Constitution prominently features.

Part III discusses what the evolution means for climate change litigation. The evolution of the locus standi and causation requirements in Kenya has helped engender change in the attitude of courts and lawmakers towards public interest and environmental protection. The consequence is that the barriers presented by the law and judicial attitudes that plaintiffs have encountered in other jurisdictions may not stand in the way of Kenyan climate litigators.

Climate change litigation in this article refers to cases before judicial and quasi-judicial bodies that seek to advance climate change mitigation and adaptation by either enforcing existing laws or seeking more ambitious regulatory targets. These include cases where climate change forms a central issue or main argument as well as cases where climate change issues are peripheral. ${ }^{15}$ In Kenya, such litigation could be based on public law (human rights or judicial review), statutory provisions (such as CCA and EMCA) or even tort law. ${ }^{16}$ While section 23 of the CCA provides the main legislative provision to enforce climate-related claims in Kenya, climate change may not always arise as a stand-alone or central issue in a case. Climate change could be canvassed in Kenya within a range of other issues, such as environmental licensing, disaster risk management or even human rights claims aimed at environmental protection, as opposed to being the core issue. $^{17}$

Considering that the CCA is yet to be litigated upon, this article canvases the jurisprudence on enforcing environmental rights based on the EMCA and the Constitution to show how the courts are likely to deal with climate litigation and interpret the enforcement provision of the CCA. ${ }^{18}$ Two key features relevant to climate change litigation stand out in this context. Firstly, locus standi has been liberalised so that any person can approach a court to enforce environmental and climate-related rights without the need to show loss or injury. Secondly, the Constitution, EMCA and CCA have created liability routes that allow litigants to avoid the restrictive causation requirements by requiring no proof of injury and application of the precautionary principle. This illustrates the potential for climate lawsuits and could 
make Kenya a potential hot spot for enforcing rights relating to climate change. ${ }^{19}$

\section{Evolution of Locus Standi and Causation}

1. The 1969 (Repealed) Constitution: The Era of Technicalities

The era of the 1969 Constitution (now repealed) is one that public interest litigators are happy to have buried in the history books. Like other East African countries, Kenya's post-independence government gave primacy to the idea of public/national security, where the state was viewed as a representation of the public's interest. ${ }^{20}$ This resulted in executive excess to the extent that attempts to challenge the government's actions were met with detention without trial, torture by security forces and other human rights abuses. ${ }^{21}$ The judiciary was either barred from reviewing executive or legislative decisions or reluctant to review or overturn executive decisions even where they were patently unconstitutional. ${ }^{22}$ Consequently, public interest litigation was rarely pursued and, when pursued, was summarily dismissed by courts. ${ }^{23}$ This period saw the rise of technical arguments

19 It is worth mentioning that public interest litigation has gained prominence in Kenya and since the promulgation of the 2010 Constitution Nairobi has become a hub for public interest litigation. There is also an increased public awareness on climate change issues and the role of government which could then lead to demand of climate action from both the government and private sector. These factors could additionally contribute to climate litigation in Kenya. See Janet C Korir, 'Level of Awareness about Climate Change among the Pastoral Community' (2019) 7 Environment and Ecology Research 197; Fredrick Okoth Okaka and Beneah DO Odhiambo, 'Urban Residents' Awareness of Climate Change and Their Autonomous Adaptive Behaviour and Mitigation Measures in the Coastal City of Mombasa, Kenya' (2018) 100 South African Geographical Journal 378.

20 Joe Oloka-Onyango, 'Human Rights and Public Interest Litigation in East Africa: A Bird's Eye View' (2015) 47 The George Washington International Law Review 1, 10.

21 Kevin Conboy, 'Detention Without Trial in Kenya' (1978) 8 Georgia Journal of International and Comparative Law 441 448-450; Albert Mumma, 'Preservation of Public Security Through Executive Restraint of Personal Liberty: A Case Study of the Kenyan Position' (1988) 21 Verfassung und Recht in Übersee / Law and Politics in Africa, Asia and Latin America 445.

22 Joseph Oloka-Onyango, When Courts Do Politics: Public Interest Law and Litigation in East Africa (Cambridge Scholars Publishing 2017) 103. It is also worth noting that the judges were appointed by the President and served at his pleasure. Whereas the judges were to be appointed upon advice of the Judicial Service Commission, all members of the commission were presidential appointees. See The Constitution of Kenya (Repealed), 1969 ss 61 and 68 . which ensured that substantive issues in public interest matters, let alone in environmental protection cases, rarely saw the light of day. ${ }^{24}$ One of the biggest hurdles in public interest cases was locus standi. ${ }^{25}$

The locus standi requirements were based on the common law restrictive approach which required plaintiffs to demonstrate a personal or proprietary interest in the matter. ${ }^{26}$ It was almost impossible to meet this threshold in public interest matters, as illustrated in Wangari Maathai \& 2 Others $v$ City Council of Nairobi (Wangari Maathai II), where the plaintiffs challenged the sale and transfer of land held by the City Council under public trust to private entities. ${ }^{27}$ The court found that the plaintiffs had failed to show that there had 'been any failure of any public duty in which they alone have a unique interest, ${ }^{28}$ noting that individuals could sue on behalf of the public only where they have sustained a particular injury as a result of a public wrong. ${ }^{29}$ Similarly, in Wangari Maathai v Kenya Times Media Trust (Wangari Maathai I), ${ }^{30}$ the court held that the plaintiff lacked locus standi, because she had not shown that the defendant breached any of her rights, nor had the defendant caused or was likely to cause damage to her. $^{31}$

In both cases, the court reiterated that only the Attorney General could sue on behalf of the public. ${ }^{32}$

23 Yash P Ghai and John Patrick WB McAuslan, Political Law and Political Change in Kenya: A Study of the Legal Framework of Government from Colonial Times to the Present (Oxford University Press 1970) 428-430; Oloka-Onyango (n 22) 103.

24 Oloka-Onyango (n 20) 10.

25 Brian Sang, 'Tending Towards Greater Eco-Protection in Kenya: Public Interest Environmental Litigation and Its Prospects Within the New Constitutional Order' (2013) 57 Journal of African Law 29, 30; Michael Ochieng Odhiambo, 'Legal and Institutional Constraints to Public Interest Litigation as a Mechanism for the Enforcement of Environmental Rights and Duties in Kenya', Fifth International Conference on Environmental Compliance and Enforcement (International Network for Environmental Compliance and Enforcement 1998) 266.

26 This was derived from the English case of Gouriet $v$ Union of Postal Office Workers [1977] AC 43 [500]. See Wangari Maathai v Kenya Times Media Trust Ltd Civ Case 5403 of 1989 (High court at Nairobi) [1989] eKLR 4; Wangari Maathai \& 2 others $v$ City Council of Nairobi \& 2 others (1994) 1 KLR (E\&L) 9; Law Society of Kenya $v$ Commissioner of Lands \& 2 Others Civ Case 464 of 2000 (High Court at Nakuru) [2001] eKLR 4.

27 Wangari Maathai II (n 26) 2.

28 ibid 9.

29 ibid 1.

30 Civ Case 5403 of 1989 (High court at Nairobi) [1989] eKLR.

31 ibid 4.

32 ibid; Wangari Maathai II (n 26) 6. 
This was a requirement under section 61 of the Civil Procedure Act, which allowed only the Attorney General or persons with his/her written consent to institute public nuisance proceedings. ${ }^{33}$ The Attorney General, however, hardly ever moved on his own to enforce public rights. ${ }^{34}$ Individuals seeking to enforce a public right were therefore left with no other recourse than the possibility of obtaining the Attorney-General's written consent, which was either almost impossible to obtain, or clouded by bureaucratic delays. ${ }^{35}$ The Attorney General was a political appointee holding his position at the President's pleasure, part of the executive, ${ }^{36}$ and a member of parliament. ${ }^{37}$ It is hard to imagine how or why the Attorney General would give written consent for a claim against the same government of which he was part.

The other option was filing a representative suit under the Civil Procedure Rules. ${ }^{38}$ Although this appeared to be a viable avenue for public interest litigation, it was particularly difficult to enforce in environmental litigation since a representative action is deemed to be on behalf of a determinate class of persons with similar interests. The nature of environmental protection cases is such that it may be difficult to specify the class of persons on whose behalf an action would be brought. ${ }^{39}$

Notably, the now-repealed Constitution did not contain any explicit provision on environmental rights. It only had a provision on the right to life, ${ }^{40}$ which was considered to encompass the right to a clean and healthy environment in Peter K Waweru v Republic. ${ }^{41}$ Notwithstanding the recognition that the right to life included a clean and healthy environment, access to justice to enforce this right was not guaranteed. Other than the restrictive locus standi requirements, the courts reacted very negatively to public interest plaintiffs, such as in Wangari Mathai I where Dugdale J held;

The plaintiff has strong views that it would be preferable if the building of the complex never took place in the interest of many people who had not been directly consulted. Of course, many buildings are being put up in Nairobi without many people being consulted. Professor Maathai apparently thinks this, is a special case. Her personal views are immaterial. The court finds that the Plaintiff has no right of action against the Defendant. ${ }^{42}$

The period after 1996 nevertheless saw creative attempts by some judges to lean towards a liberalised approach to locus standi. In Alfred Njau \& 5 others $v$ City Council of Nairobi, ${ }^{43}$ the court held that an individual may sue where the Attorney General refuses unreasonably to exercise his power to initiate proceedings or if there is insufficient time to seek his consent. ${ }^{44}$ This case created space for members of the public to bring public interest suits where the Attorney General had acted unreasonably. It did not actually happen in practice as the courts still required the aggrieved member to show "sufficient interest". ${ }^{45}$ The term "sufficient interest" was never defined by case law but was applied by most courts in a manner that restricted standing. ${ }^{46}$

Some judges nevertheless interpreted "sufficient interest" liberally. In Paul Nderitu Ndung'u \& Others
33 Civil Procedure Act (Chapter 21 Laws of Kenya) s 61(1).

34 Odhiambo (n 25) 267.

35 ibid.

36 The Constitution of Kenya (Repealed), 1969 s 26.

37 ibid 36. The provision designated the Attorney General as an exofficio member of National Assembly.

38 The Civil Procedure Rules, which mainly governed the process of public interest matters in civil courts at that time, provides that a person may file a representative suit on behalf of other people with the same interest in one suit. See Civil Procedure Rules Order 1 rule 8(1).

39 Odhiambo (n 25) 266-267.

40 The Constitution of Kenya (Repealed), 1969 s 71.

41 Peter K Waweru v Republic [2006] MisCivl Appli.No 118 of 2004 (High Court at Nairobi [2006] eKLR 11. The case was however not about enforcing environmental rights through the right of life provision, but rather the judge made this pronouncement suo motu. The Applicants had been charged with the offence of discharging raw sewerage into public water and filed a constitutional reference challenging the charges on the ground of discrimination. Even though they were discharged on this ground, the judge found that their actions were a threat to people's right to clean and healthy environment, and that the right to life could be threatened by many things including the environment. The judge then suo motu ordered a remedial action to be taken by the government. For a further analysis of the case, see Omuko-Jung ( $\mathrm{n}$ 16).

42 Wangari Maathai I (n 10) 4.

43 Alfred Njau \& 5 others $v$ City Council of Nairobi Civ Appeal 74 of 1982 (Court of Appeal at Nairobi) [1983] eKLR.

44 ibid 14.

45 ibid. See also Odhiambo (n 25) 267.

46 Wangari Maathai II (n 26) 6; Law Society of Kenya (n 26) 12; Odhiambo (n 25) 267. 
$v$ Pashito Holdings Limited and Another, ${ }^{47}$ the plaintiffs challenged the alienation of public land reserved for a water reservoir. Justice Mbogholi-Msagha pointed out that " $t$ the submission that the Attorney General is the only competent authority to institute a suit on behalf of the public is restrictive and may lead to miscarriage of justice." ${ }^{48}$ While noting that the wider public interest in the matter must be considered, the judge found that the plaintiffs had a "sufficient interest" because the provision of a water reservoir could not be divorced from the plaintiffs' personal welfare. $^{49}$

Another example is Abdikadir Sheikha Hassan and Others v. Kenya Wildlife Service (Hassan v KWS) where the court used customary law to find sufficient interest. ${ }^{50}$ The court permitted the plaintiffs to bring a suit seeking to restrain the defendant from removing a rare and endangered animal from its natural habitat to a national park. It observed that according to customary law, those entitled to use the land are also entitled to the fruits thereof, including the fauna and flora. Thus, the applicants had the standing to challenge the agency's action. ${ }^{51}$ These were, however, just a few rulings, and most judges were more comfortable sticking to the restrictive approach. There was no legal basis for the liberal approach making judges overly cautious in creating jurisprudence that liberalised locus standi.

The jurisprudence on causation is more obscure. Causation usually plays a role at two stages in a trial - firstly as part of the locus standi enquiry and secondly at the merits stage. At the locus standi stage, the plaintiffs needed to demonstrate that the defendant's action or inaction had injured them over and above that of the public. For instance, in Wangari Maathai I, the court found that the plaintiff lacked standing as there was no allegation that the defendant caused damage to the plaintiff. ${ }^{52}$ To the author's knowledge, there is no Kenyan case law on causation at the merits stage in public interest environmental matters. As pointed out above, the public interest cases were rare and summarily thrown out by court when pursued, ${ }^{53}$ which explains this jurisprudential gap.

2. Enactment of EMCA: Legislative Move towards a Liberal Approach

The enactment of the EMCA in $1999^{54}$ saw a move towards a more liberal approach to locus standi and causation which made public interest environmen- tal litigation possible. First, the EMCA recognised the right to a clean and healthy environment to which every person in Kenya is entitled and has a duty to safeguard and enhance. ${ }^{55}$ Placing the duty to safeguard and enhance the environment on every person in Kenya meant that every person potentially had locus standi in environmental cases. ${ }^{56}$

Section 3(3) of the EMCA allows any person who alleges that their entitlement to a clean and healthy environment is being or is likely to be contravened to apply to the High Court for redress. ${ }^{57}$ Crucially, this right exists even if they cannot show that the defendant's act or omission has caused or is likely to cause them any personal loss or injury. ${ }^{58}$ The only limiting factor of section 3(3) is that the person whose right has been or is likely to be allegedly violated is the one to approach the court to enforce the right. This provision did not enable a person to enforce this right on behalf of another or group of persons. In practice, however, the provision did not really limit standing since plaintiffs did not have to show injury or could still rely on section 3(1) of the EMCA, which places a duty to protect the environment on every person in Kenya. Claims for enforcement of this right could still be framed as environmental protection suits, which would benefit from the wider standing under section 3(1).

\footnotetext{
47 H.C. Civ case 3063 of 1996, 1 Casebook on Environmental Law 124.

48 ibid 128

49 ibid 126. Even though plaintiffs did not show any special interest over and above that of the public that would benefit from the reservoir, the court still discerned a "personal interest" by associating the provision of water with personal welfare.

50 (1996) 1 KLR (E\&L).

51 ibid 2.

52 Wangari Maathai I (n 10) 4.

53 Oloka-Onyango (n 20) 10; National Environmental Complaints Committee, 'Public Interest Litigation Draft Manual' 9-10 <https://www.necc.go.ke/wp-content/uploads/2019/02/PIL -MANUAL.pdf> accessed 29 June 2021.

54 EMCA.

55 ibid 3(1).

56 In Joseph Leboo \& 2 others $v$ Director Kenya Forest Services \& Another ELC Case No 273 of 2013 (ELA at Eldoret) [2013] eKLR [28], the judge noted that any person is free to commence litigation to ensure protection of the environment.

57 EMCA s 3(3). See also Section 111 EMCA which provides that any person can institute proceedings for environmental restoration, and it shall not be necessary for a plaintiff to show that they a right or interest in the property, environment or land alleged to have been or likely to be harmed.

58 ibid 3(4)
} 
One significant aspect of EMCA is its primacy clause (section 148) which provides that the EMCA prevails where there is a conflict between any existing law and the EMCA on environmental management. ${ }^{59}$ The primacy clause provides the basis for a determinate and principled approach to any contradictions or lack of clarity arising from the application of different sources of law in environmental matters. ${ }^{60}$ One example is the afore-mentioned Civil Procedure Act which provides that public nuisance suits are to be instituted by the Attorney General or persons with the written consent of the Attorney General. ${ }^{61}$ If an environmental suit is based on public nuisance, then under the EMCA's primacy clause, the conflict between section 61 of the Civil Procedure Act and the EMCA will be resolved by applying the locus standi requirements in the EMCA, which are more liberal. This was tested in Rodgers Muema Nzioka and Others $v$ Tiomin Kenya Limited (Rodgers Mue$m a),{ }^{62}$ where the judge noted that the issue of whether to grant an interlocutory injunction could be decided by applying various principles including tort-law principles. Nevertheless, the judge relied on the EMCA to determine whether the claimant was entitled to institute an action and had a case with a probability of success. ${ }^{63}$

It did not take long for the courts to start applying the liberal approach to environmental litigation. In one of the first cases decided after the EMCA's enactment, the defendants in Insurance Company of

59 ibid 148

60 Sang (n 25) 44.

61 Civil Procedure Act s 61(1).

62 Civ. Case 97 of 2001 (High Court at Mombasa) [2001] eKLR.

63 ibid 3.

64 Civ. suit 135 of 1998 (High Court at Mombasa) [2001] eKLR.

65 ibid 6.

66 ibid 9.

67 Rodgers Muema (n 62) 2.

68 ibid 3.

69 ibid 5 .

70 Wangari Maathai I (n 10) 4.

71 EMCA s 3(3).

72 Elijah Ole Kool v George Ikonya Thuo Civ case 1299 of 1998 (High Court at Nairobi) [2001] eKLR 3.

73 Principle 15 of the Rio Declaration on Environment and Development; Nicolas de Sadeleer, Environmental Principles: From Political Slogans to Legal Rules (Oxford University Press 2002) 153; Lydia Akinyi Omuko, 'Applying the Precautionary Principle to Address the "Proof Problem" in Climate Change Litigation' (2016) 21 Tilburg Law Review 52, 54, 61-62.
East Africa $v$ The Attorney General \& Others (ICEA v $A G)^{64}$ argued that the plaintiff lacked standing to challenge the allocation of a road reserve to private persons. The defendants alleged that the plaintiffs lacked standing since they did not have any interest except a claim of access to the ocean as a member of the public. ${ }^{65}$ Since the case raised public rights and environmental implications, Justice Waki relied on the EMCA provision to point out that 'when it comes to environmental matters, ...the ogre of locus standi which ha[d] for a long time shackled courts of law must be tamed. ${ }^{166}$ In Rodgers Muema, the plaintiffs sought an injunction to restrain the defendants from undertaking mining activities because titanium excavation was likely to trigger multifarious environmental and health problems, and the requisite environmental impact assessment (EIA) had not been conducted. ${ }^{67}$ The defendants challenged the plaintiffs' standing, arguing that the plaintiffs did not have a proprietary interest and were mere squatters. ${ }^{68}$ The judge held that the plaintiffs did not need to show that they had a right or interest in the property, environment or land alleged to be invaded, but the fact that they were entitled to a clean and healthy environment gave them a right to prosecute the case. $^{69}$

The other significance of the EMCA provisions relates to causation at both locus standi and merits stage. During the pre-EMCA period, plaintiffs were required to show the link between the breach of rights or the plaintiff's injury and the defendant's action to prove they had standing. ${ }^{70}$ The removal of the requirement to 'show that the defendant's act or omission has caused or is likely to cause him any personal loss or injury ${ }^{71}$ for capacity to sue did away with this causation requirement of locus standi.

Regarding the merits stage, the general rule on causation in Kenya is that a defendant will only be held liable if his act or omission is either the effective cause of the plaintiff's injury or is so connected with it that it is considered a cause materially contributing to the injury. ${ }^{72}$ What EMCA did is to provide a statutory route to liability that allows litigants in environmental matters to avoid the restrictive causation requirement through the application of the precautionary principle. The precautionary principle is an environmental principle that requires decisionmakers to take measures to prevent a substance from causing harm even if there is no conclusive scientific proof linking the activity to the harm. ${ }^{73}$ Section 3 
of the EMCA mandates the courts to be guided by the precautionary principle in exercising jurisdiction under the EMCA. ${ }^{74}$ Indeed, the courts started taking a precautionary approach post-EMCA so that any activities that were potentially harmful to the environment were considered likely to cause injury to the public. There was no need for the plaintiffs to point out an injury. In Rodgers Muema, the court noted that environmental degradation is not necessarily an individual concern, but a public loss and any form of feared degradation is considered detrimental to the population. ${ }^{75}$ Furthermore, the courts while making decisions in environmental cases were 'concerned not so strictly with harm to the environment but rather the failure of decision makers to take environmental factors into account in a way that the EMCA prescribes. ${ }^{76}$ This confirms that the plaintiffs did not have to prove how the activities complained of harmed or were likely to degrade the environment, let alone showing a link between the activities and an injury.

However the picture was not all rosy. Some judges still upheld the common law position requiring some personal interest as a basis for standing under EMCA. This was particularly common in suits challenging the issuance of EIA licences under section 129 of the EMCA. The section provides that a person $a g$ grieved by the grant or refusal of a licence may appeal to the National Environment Tribunal (NET). ${ }^{77}$ Some courts interpreted this provision to limit the standing of those who can appeal to persons who applied for the licence. ${ }^{78}$ In Republic $v$ NET, ex parte $O l$ Keju Ronkai Limited and Another ${ }^{79}$ the court held that a person who did not participate in the EIA study or the approval process of the development cannot be said to have been aggrieved by the process which led to the issuance of the licence, as no decision has been made against him. ${ }^{80}$

The High Court in NET v Overlook Management Limited \& 5 others ${ }^{81}$ took a similar position by holding that NET's jurisdiction to hear appeals could only be invoked by parties who were or are affected by the grant or denial of licences. The judge was of the view that the new relaxed rules on locus standi only applied in the High Court, and not the NET. ${ }^{82}$ The Court of Appeal reversed this finding, holding that the expanded locus standi in environmental matters extends to every Kenyan. ${ }^{83}$ The Court of Appeal's decision was made in 2019, sometime after the introduction of current constitutional provisions (dis- cussed below). The judges applied the law as it was when the EIA licence was granted (in 2006) and therefore did not apply the constitutional provision on 10 cus standi but rather the EMCA's. ${ }^{84}$ The 2010 Constitution, however, had a significant influence on the judges' approach to technicalities in environmental protection matters.

3. Promulgation of the 2010 Constitution: Constitutional Stamping of Liberalisation

The $27^{\text {th }}$ of August 2010 was a turning point for public interest litigation in Kenya. The Constitution, promulgated on this day, provides an expansive Bill of Rights covering a range of economic, social, cultural, civil, and political rights, ${ }^{85}$ including the right to a clean and healthy environment. ${ }^{86}$ These are complemented by permissive provisions on access to justice to ensure that the Bill of Rights is enforceable. These include provisions with broad standing ${ }^{87}$ directing courts not to be restricted by technicalities and formalities, ${ }^{88}$ and placing the duty to respect and uphold the Constitution on both the government and private persons. ${ }^{89}$ An important aspect is that the Constitution allows for horizontal application of rights. Pursuant to Article 20(1) of the Constitution, the Bill of Rights binds all state organs and all persons, ${ }^{90}$ and person under the Constitution includes "a company, association or other body of persons

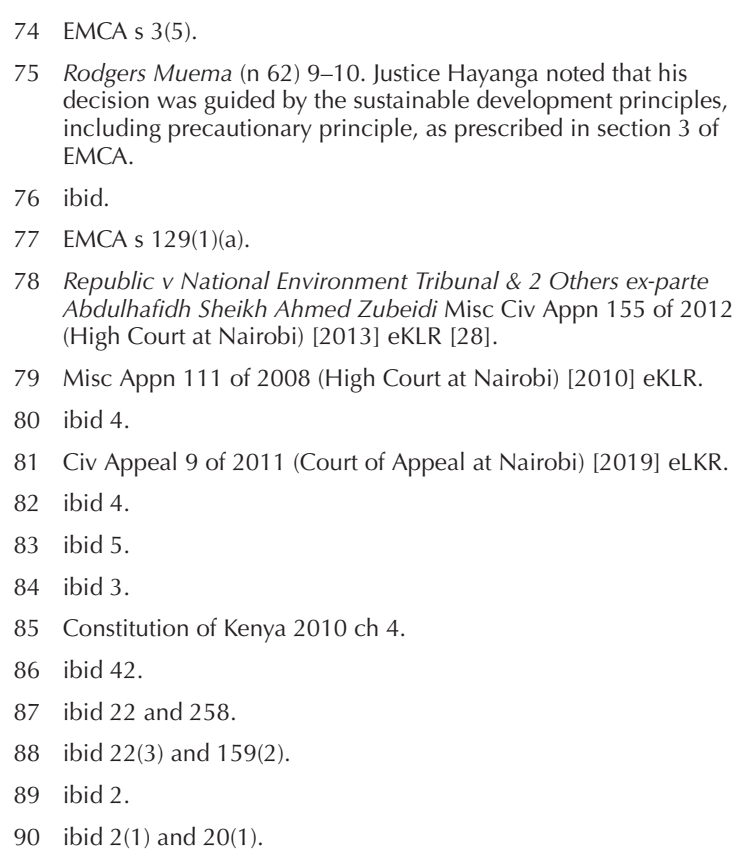


whether incorporated or unincorporated." ${ }^{\prime 91}$ The courts have indeed confirmed that the Bill of Rights can be directly invoked against private entities. ${ }^{92}$

The promulgation of the 2010 Constitution finally made it clear that technicalities will no longer bar public interest matters and particularly environmental protection. First and foremost, the protection of the right to a clean and healthy environment, ${ }^{93}$ means that the provisions on the enforcement of the Bill of Rights apply where this right is relied upon. Article 22 (1) of the Constitution provides the standing to enforce the Bill of Rights to every person. ${ }^{94}$ This includes a person acting on behalf of another, as a member of or in the interest of a group, acting in the public interest or an association acting in the interest of its members. ${ }^{95}$ This provision allows every person in Kenya to enforce the right to a clean and healthy environment.

The provision is augmented by Article 70 of the Constitution, which provides for enforcement of environmental rights. Under the provision, 'if a person alleges that a right to a clean and healthy environment recognised and protected under Article 42 has been, is being or is likely to be, denied, violated, infringed or threatened, the person may apply to a court for redress. ${ }^{96}$ The provision provides that if a person alleges that 'a right', not their right, meaning that the right to a clean and healthy environment does not have to be enforced by the persons whose rights have been violated or threatened but can be enforced by anyone. This is a progression from the EMCA which did not permit a person to approach the court on behalf of another. ${ }^{97}$ Furthermore, the applicant is not required to demonstrate any loss or damage to enforce environmental rights. ${ }^{98}$ Thus, the courts do not require identification of any person(s) affected or likely to be affected but instead take the view that any possible or imminent environmental degradation is to the detriment of the public and acknowledge that every person has a duty to protect the environment. ${ }^{99}$

By doing away with the need to show injury, the Constitution, just like EMCA, removed the causation requirement for standing and created a liability route that allows environmental litigants to avoid the restrictive causation requirement at the merits stage. In practice, the courts have not required the claimants to provide step-by-step scientific evidence linking any injuries to defendants' actions to succeed in enforcing environmental rights. The plaintiffs are mainly required to show how the defendants' activities are affecting or likely to affect the quality of environment. ${ }^{100}$ Even in such cases, some courts have not required the plaintiff to provide scientific evidence of the actual or likely effects of the defendants' activities on the environment. Rather, they have accepted the general evidence of the likely impacts of such actions. A case in point is Ken Kasing'a v Daniel

91 ibid 260

92 In fact, the courts consider the issue of whether the constitutional rights can be applied horizontally to be beyond peradventure and completely settled. See Satrose Ayuma \& 11 others v Registered Trustees of the Kenya Railways Staff Retirement Benefits Scheme \& 3 others Pet 65 of 2010 (High Court at Nairobi) [2013] eKLR; Isaac Ngugi v Nairobi Hospital \& 3 others Pet 407 of 2012 (High Court at Nairobi) [2013] eKLR; Rose Wangui Mambo and 2 Others v Limuru Country Club and 17 Others Pet 160 of 2013 (High Court at Nairobi) [2014] eKLR [78]; B A \& another $v$ Standard Group Limited \& 2 Others Civil Appeal No 224 of 2012 (Court of Appeal at Nairobi) [2016] eKLR [34]; Baobab Beach Resort and Spa Limited v Duncan Muriuki Kaguuru \& Another Civil Appeal No 296 of 2014 (Court of Appeal at Nairobi) [2017] eKLR 6.

93 Constitution of Kenya art 42 provides for the right to a clean and healthy environment.

94 ibid 22 (1). It provides that, 'Every person has the right to institute court proceedings claiming that a right or fundamental freedom in the Bill of Rights has been denied, violated or infringed, or is threatened.'

95 ibid 22(2); Kiluwa Limited \& another $v$ Commissioner of Lands \& 3 Others Pet 8 of 2012 (High Cout at Mombasa) [2015] eKLR [32].

96 Constitution of Kenya s 70(1)

97 Section 3(3) EMCA previously provided for access to court only to the person whose rights had allegedly been violated. The provision has since been amended to allow persons to file suits on their behalf or on behalf of other persons and associations or in the public interest

98 Constitution of Kenya art 70(3). Article 70 of the Constitution provides that:

(1) If a person alleges that a right to a clean and healthy environment recognised and protected under Article 42 has been, is being or is likely to be, denied, violated, infringed or threatened the person may apply to a court for redress in addition to any other legal remedies that are available in respect to the same matter

(2) .....

(3) For the purposes of this Article, an applicant does not have to demonstrate that any person has incurred loss or suffered injury.

99 See Moffat Kamau \& 9 others v Aelous Kenya Limited \& 9 others Pet 13 of 2015 (ELC at Nakuru) [2016] eKLR [94]; Rodgers Muema (n 62) 4-5. Article 69(2) of the Constitution further places on every person the duty to cooperate with State and other persons to protect and conserve the environment.

100 See Adrian Kamotho Njenga v Council of Governors \& 3 Others ELC Pet 37 of 2017 (ELC at Nairobi) [2020] eKLR where the court pointed out that a clean and healthy environment would be one that is devoid of dirt or anything harmful which may interfere with the physical or mental well-being of person. 
Kiplagat Kirui \& 5 Others (Ken Kasing'a), ${ }^{101}$ where the court found that the petitioner's right to a clean and healthy environment had been violated by the erection of a telecommunication base transmitter station in the adjacent land. There was no evidence presented on the impacts of the defendant's telecommunication transmitters on the environment. The court considered the evidence that telecommunication base transmitter stations generally have the potential to harm the environment and people through emissions of electromagnetic waves. ${ }^{102}$ Through the application of the precautionary principle, the courts assume that certain projects are likely to harm the environment or people and the onus is on the defendant to prove that the specific project is not harmful, or the potential harm has been mitigated. This approach shifts the burden of proof to the defendant so that the plaintiff is not required to show that the defendant's action is (potentially) harmful, but it is presumed that the project is harmful to the environment and people, and it is for the defendant to rebut this. ${ }^{103}$

Additionally, courts take the view that non-compliance with procedural environmental obligations contained in statutes or regulations amount to violation of the right to a clean environment. ${ }^{104}$ Non-compliance in this case is not only limited to whether a project has obtained an EIA licence or not but also includes other duties provided in law. These duties could be failure to take material considerations into account in project approval, ${ }^{105}$ failure to undertake

101 Pet 50 of 2013 (ELC at Nakuru) [2015] eKLR.

102 ibid 74.

$103 \mathrm{ibid}$ 73. The judge noted that where the precautionary principle is invoked, the burden of proof ought to rest upon the proponent of the project, who needs to demonstrate that the project at hand is not harmful to the environment or that the harm to the environment is tolerable.

104 In Ken Kasinga (n 97) para 73, Justice Munyao Sila held that where a procedure for the protection of the environment is disregarded, then an assumption is drawn that the project violates the right to a clean and healthy environment or at least has potential to harm the environment. See also Moffat Kamau (n 99) paras 90-91 and 95.

105 Sam Odera and 3 Others vs National Environmental and Management Authority \& Another Misc. Civil Appl 400 of 2006 (High Court at Nairobi) [2006] eKLR. See Part III below for a discussion of material considerations.

106 Republic vs Kenya Forest Service exparte Clement Kariuki \& 2 Others JR Case 285 of 2012 (High Court at Nairobi) [2013] eKLR.

107 Sam Odera (n 105) 6.

108 The project report is a precursor of EIA study report. Upon studying the EIA project report and being satisfied that the intended effective public participation, ${ }^{106}$ or even failure to consider environmental principles such as the precautionary principle in decision-making. ${ }^{107}$ In Ken Kasing'a, the court found that the petitioner's right to a clean and healthy environment had been violated because the project development started before the issuance of an EIA licence and an EIA study report had not been submitted as required by EMCA. ${ }^{108}$ There was also a lack of public participation in preparation of the EIA project report. ${ }^{109}$

The courts have repeatedly made it clear that they will not entertain any attempts to restrict access to court for enforcement of environmental rights, ${ }^{110} \mathrm{in}$ cluding any statutory provisions that do so. Statutory provisions with restrictive locus standi requirement are to be interpreted in a manner consistent with the Constitution. ${ }^{111}$ This would, for instance, apply to environmental suits based on public nuisance. Rather than such a suit being instituted only by the Attorney General as required by section 61 the Civil Procedure Act, the courts will allow any person to file such a case. ${ }^{112}$ In Edward Onsongo v Job Mogusu (Edward Onsongo), the Court noted that Section 61 of the Civil Procedure Act needs to be read in light of section 3 the EMCA and Articles 21, 42 and 70 of the Constitution ${ }^{113}$ and consequently held that:

[I]f the Constitution, the supreme law of the land removes the requirement of locus standi in environmental disputes lodged before this court, this court should not fetter itself with discordant provisions of a statute that has not been amended to

project may have a significant impact on the environment, the national environmental authority will usually direct the proponent to conduct an EIA and present a study report. EMCA s 58; Ken Kasinga (n 101) para 54.

109 Here the judge referred to the principle from international declarations such as Rio Declaration and Bali Guidelines for the Development of National Legislation on Access to Information, Public Participation and Access to Justice in Environmental Matters. Ken Kasinga (n 101) paras 53-71.

110 Moffat Kamau (n 99) para 68; Joseph Leboo (n 56) para 21. In Moffat Kamau the defendants' attempts to challenge the plaintiffs standing on the ground that the project was not situated on their land was rejected by court. The court reiterated that any person, even an individual not resident and who owns no land in the area, could have filed the petition challenging the development of the project.

111 Considering the supremacy of the Constitution, courts are required to interpret statutes in a manner consistent with the Constitution and this applies to locus standi in environmental matters as well. See note 93 above

112 Edward Nyaoga Onsongo v Job Mekubo Mogusu ELC Case 129 of 2017 (ELC at Kitale) [2019] eKLR [12].

113 ibid 15. 
rhyme with the spirit of the Constitution, for to do so would amount to denying a citizen of a constitutional right to be heard on his own accord as an individual on matters environment. ${ }^{114}$

The EMCA also continues to apply in environmental matters, and there have been recent amendments to bring it in line with the Constitution. One of the amendments is to section 3(3), which previously allowed only those whose rights had been or likely to be infringed to enforce it. Section 3(3) now provides that 'that person may on his behalf or on behalf of a group or class of persons, members of an association or in the public interest apply to the Environment and Land Court for redress, ${ }^{115}$ extending locus standi to associations, those suing on behalf of others and in the public interest.

4. The Climate Change Act, 2016: Concretising Liberalised Locus Standi

Enacted in May 2016, the CCA provides the regulatory framework to enhance climate change resilience and low-carbon development in Kenya. Government entities are required to apply the CCA to all sectors of the economy and to mainstream climate change responses in their planning and decision-making. ${ }^{116}$ In addition to the duties in the CCA, the National Climate Change Council (the Council) may impose climate change duties on both public and private entities. ${ }^{17}$ The CCA further provides that the rights and duties conferred by it are in addition to those con-

\footnotetext{
114 ibid 18.

115 EMCA (Revised Edition 2012) s 3(3).

116 Climate Change Act s 3.

117 Ibid 15-16. Under both provisions, the Council may establish regulations imposing duties on private and public entities, including duties to report and monitor their GHG emissions.

118 ibid 3(3)

119 ibid 23.

120 It is also important to note that cases under Section 23 of the CCA are to be filed before the ELC, which has a history and experience in adjudicating environmental matters.

121 NET Appeal No 196 of 2016 [2019] eKLR.

122 ibid 154. For a comprehensive analysis of the case, see Anyango and Odaga (n 17) 129.

123 Lamu Coal Power (n 121) para 138.

124 Ibid para 139. Interestingly, this is one of the cases where the applicants' locus standi was never challenged as relates to the meaning of aggrieved person under Section 129(1) of EMCA. This shows the general acceptance that aggrieved person does not necessarily mean the person directly affected by the grant or denial of a licence.
}

ferred by any other law, ${ }^{118}$ meaning that it can, for instance, be applied in conjunction with the EMCA.

More importantly, the CCA has incorporated the liberal locus standi requirements in its provision on enforcement of climate-related rights. ${ }^{119}$ According to section 23 of the CCA, 'any person may, pursuant to Article 70 of the Constitution, apply to the Environment and Land Court (ELC) alleging that a person has acted in a manner that has or is likely to adversely affect mitigation and adaptation efforts.' This provision, coupled with the constitutional and EMCA provisions, allows access to courts to anyone to hold private entities and government liable for their action or inaction relating to climate change. The importation of Article 70 of the Constitution into the climate change enforcement provisions gives a direct reference for potential climate litigators to file the cases as constitutional matters and arguably places climate related violations at the same level as constitutional rights violations.

There has not, as yet, been any proceedings brought under section 23 of the CCA. Considering the similarity of section 23(3) of CCA with Article 70(3) Constitution and section 3(4) of EMCA, the courts are likely to take the same interpretive approach on $l^{-}$ cus standi and causation. ${ }^{120}$ Consequently, constitutional and EMCA jurisprudence will play a huge role in developing the courts' approach to section 23(3). The duties under the CCA have, however, been relevant in litigation before the NET in Save Lamu \& Others $v$ National Environmental Management Authority (NEMA) \& Another (Lamu Coal Power). ${ }^{121}$ In the case filed under the EMCA, the NET revoked the EIA license issued for the development of a 1050MW coal power plant near the UNESCO world heritage site of Lamu for failure, among others, to consider and comply with the CCA. ${ }^{122}$ The respondents argued that their failure to consider the CCA was because the legislation was enacted during the process of the study. The NET nevertheless held that climate change issues are pertinent to projects like this and all relevant laws, including the CCA, must be considered and complied with. ${ }^{123}$ The NET also found that applying the precautionary principle meant that where there is lack of clarity on the consequences of certain aspects of the project, they had to reject the project. It found that this was of particular importance in issues relating to climate change, and that a process (in this case an EIA) that failed to take climate change into account would be incomplete and inadequate. ${ }^{124}$. 


\section{Impact of the Evolution on Climate Litigation in Kenya}

The exciting potential that the liberalised locus stan$d i$ and causation requirements create for climate litigation cannot be overstated. These two concepts are among the most challenging hurdles for plaintiffs in climate litigation. ${ }^{125}$ While legal definitions of locus standi differ across jurisdictions, claimants are generally required to show that they have a genuine stake in the outcome, the dispute can be resolved by court, and the court is capable of providing a remedy. ${ }^{126} \mathrm{In}$ the U.S, the plaintiffs have to show an injury-in-fact, causation and redressability. ${ }^{127}$ In applying this standard, the court found that the claimants in Juliana $v$ U.S lacked standing for not fulfilling the redressability part. ${ }^{128}$ The European General Court in the Carvalho case, on the other hand, found that the plaintiffs lacked standing because they were not sufficiently and directly affected by the challenged policies. ${ }^{129}$ The court concluded that climate change affects every individual, and the plaintiffs need to show that they are affected by the contested act in a manner that is 'peculiar to them or by reason of circumstances in which they are differentiated from all other persons. ${ }^{130}$ Similarly in Smith v. Fronterra, the Auckland High Court found that the plaintiff lacked standing to pursue nuisance claims against major greenhouse gas emitters, since the alleged damage was no more serious than that suffered by the general public. ${ }^{131}$ Closer home, a Nigerian High Court in Oronto Douglas v Shell Petroleum Development Company Nigeria Limited ${ }^{132}$ held that the plaintiff

125 United Nations Environment Programme (n 15) 37-39; Byers, Franks and Gage (n 1) 278-279; Brian J Preston, 'Climate Change Litigation (Part 1)' (2011) 5 Carbon \& Climate Law Review 3, 8; Doglas A Kysar, 'What Climate Change Can Do About Tort Law' (2011) 4 Environmental Law 1, 29

126 United Nations Environment Programme (n 15) 37.

127 United States Constitution s III; Lujan v. Defenders of Wildlife (n 2) 560-561.

128 In Juliana v United States [2020] No18-36082 (9th Circ), the court held that the plaintiffs lacked standing to file constitutional climate claim because the court could not provide the proper remedy. According to the court, the prayers sought were complex policy decisions which are entrusted to the executive and political branches.

129 Carvalho v Parliament and Council (n 1) para 54. This decision was recently upheld by the European Court of Justice on appeal. The ECJ reiterated that the plaintiffs' claims are inadmissible on standing grounds for failing to demonstrate that the plaintiffs were individually impacted by Europe's climate policy. See C- -565/19 P-Armando Carvalho and Others $v$ European Parliament and Council of the European Union [2021] ECLI:EU:C:2021:252. lacked standing to challenge a gas project for noncompliance with the EIA process. The court was of the view that the plaintiff had not shown that his private right was affected, nor any direct injury caused to him. ${ }^{133}$ The result has been a denial of access to justice for climate-related violations, as most climate cases are dismissed before their merits can be considered.

Nevertheless, claimants have found new strategies that provide routes around the restrictive standing and causation requirements, which has led to some positive decisions from courts. One of the strategies has been the invocation of fundamental rights and the state's duty to protect. ${ }^{134}$ When enforcing fundamental rights, claimants are not required to show that they have been particularly affected in a manner that differentiates them from other members of the public. ${ }^{135}$ Violation of fundamental rights and the state's duty to protect is considered to individually affect persons and consequently, individuals have standing in case of a possible violation. ${ }^{136}$ This was the case in Neubauer, et al. v. Germany, where the court found that a possible violation provided a ground for standing to challenge the constitutionality of the German Federal Climate Change Law. The court noted that in constitutional proceedings, 'it is not generally required that complainants are especially affected - beyond simply being individually affected - in some particular manner that differentiates them from all other persons. ${ }^{137}$ In Juliana $v$ U.S, the causation requirement for standing was met due to the alleged government agencies' failure to act in areas where they had authority, especially because they had juris-

130 ibid 45 and 50

131 Smith v. Fronterra Co-Operative Group Limited (n 1) para 62.

132 Unreported Suit No: FHC/L/CS/573/96, 17 February 1997 (as cited in Uzuazo Etemire, 'The Future of Climate Change Litigation in Nigeria: COPW v NNPC on the Spotlight' Carbon \& Climate Law Review, at 158 of this edition).

133 For comprehensive analysis of the case, see Etemire (n 128), 158.

134 Setzer and Byrnes (n 6) 14-18 and United Nations Environment Programme (n 15) 13-16 show the increase in human rightsbased climate cases.

135 Neubauer, et al $v$ Germany BVerfG, Beschluss des Ersten Senats vom 24 März 2021 - 1 BvR 2656/ 18, 1 BvR 288/20, 1 BvR 96/20, 1 BvR 78/20 - Rn (1 - 270) [110]. (Unofficial English translation available at the Sabin Centre Climate Case Charts <http://climatecasechart.com/climate-change-litigation/non-us -case/neubauer-et-al-v-germany/> accessed on 30 June 2021).

136 ibid 97-100.

137 ibid 110 
diction over sectors producing about $64 \%$ of U.S emissions. ${ }^{138}$

The rise of rights-based cases corresponds with the increased application of the precautionary principle in climate cases. Courts have noted that upholding fundamental rights requires observance of the precautionary principle and found a violation of the duty to protect where no precautionary measures have been taken. ${ }^{139}$ For instance, in Netherlands $v$ Urgen$d a$, the Dutch Supreme Court rejected the state's argument that Articles 2 and 8 ECHR $^{140}$ do not oblige the state to offer protection from the threat of dangerous climate change because the threat was not specific enough but global. ${ }^{141}$ On the contrary, the court held that protections under Articles 2 and 8 ECHR include the state's duty to take preventive measures against danger, even if it is uncertain that the danger will materialise. ${ }^{142}$

These global trends show how the liberalised locus standi and causation requirements in Kenya provide the needed legal opportunities for climate litigation. However, whether a climate case would benefit from the liberalised locus standi and causation depends on

138 Juliana v United States 217 F Supp 3d 1224 (D Or 2016) 1244-1246; Juliana v U.S (n 1) 2.

139 Neubauer $v$ Germany (n 135) 152; State of the Netherlands $v$ Urgenda Foundation [2019] ECLI:NL:HR:2019:2007 (Supreme Court of the Netherlands) [7.2.5]; Demanda Generaciones Futuras v Minambiente (Future Generations v Ministry of the Environment and Others) Radicación $n^{\circ}$ 11001-22-03-000-2018-00319-01; STC4360-2018 (unofficial translation of the excerpts of the judgement available at the Sabin Centre Climate Case Charts <http://climatecasechart.com/climate -change-litigation/non-us-case/future-generation-v-ministry -environment-others/> accessed on 30 June 2021).

140 European Convention on the Protection of Human Rights and Fundamental Freedoms. Article 2 protects the right to life while Article 8 protects the right to respect for private and family life.

141 Netherlands $v$ Urgenda (n 139) para 5.1.

142 ibid 5.3.2

143 See part I of this article.

144 Omuko-Jung (n 16) 401. See also Etemire (n 128) // for a discussion of the challenges or difficulty of litigating climate change under tort law.

145 Edward Onsongo (n 112) para 15.

146 Adrian Kamotho (n 100) para 22.

147 EMCA pt VIII.

148 In Moffat Kamau, the judge reiterated the need for public bodies to follow procedures in protecting the environment and stated, '[W] here a procedure for the protection of the environment is provided by law and is not followed, then an assumption ought to be drawn that the project is one that violates the right to a clean and healthy environment, or at the very least, is one that has potential to harm the environment.' See Moffat Kamau (n 99) para 90; Ken Kasinga (n 101) para 73.

149 Climate Change Act s 16 the basis upon which the case is grounded. As already pointed out, climate change litigation in Kenya could be based on various grounds and climate change could be canvassed within a range of other issues as opposed to being the core issue. ${ }^{143}$ An example is the Lamu Coal case where climate change arose within an EIA licencing case filed under EMCA. Such type of climate litigation (where climate change issues are peripheral) are likely to be filed under non-climate statutes and the framing will need to comply with the applicable statutory requirements. Depending on the type of case, and the applicable statute, the different locus standi and causation requirements will apply.

Climate cases would benefit from the liberalised locus standi and causation requirements if framed as public interest matters or if litigated under the CCA and EMCA as opposed to being tort-based. In tortbased cases, plaintiffs are still required to prove that they have suffered an injury and that the injury results from the defendant's action. ${ }^{144}$ This is with the exception of the tort of public nuisance. The courts have held that a public nuisance environmental case would be subject to the constitutional and EMCA provisions on locus standi as opposed to the civil procedure rules. ${ }^{145}$

What kind of climate cases would benefit from the liberalised environmental and climate protection laws discussed in this article? One argument would be that an entity's conduct (such as high emitting activities) or the government's inaction or project approval amounts to a violation of constitutional rights and specifically the right to a clean and healthy environment under Article 42 of the Constitution. A clean and healthy environment has been defined as one devoid of dirt or anything harmful with may interfere with the well-being of persons. ${ }^{146}$ EMCA lists emissions causing or likely to cause air pollution as one of the factors deleterious to the environment. ${ }^{147}$ Considering case law and the EMCA, GHG emissions would be considered as impacting the quality of the environment and could therefore be a basis for a constitutional claim against emitting entities.

Additionally, failure to comply with environmental regulations or statutory duties leads to a presumption of a violation of the right to a clean and healthy environment. ${ }^{148}$ This could also form a basis for a suit under section 23 of the CCA. The CCA envisages climate change duties being imposed on both public and private entities. ${ }^{149}$ The Council is required to make regulations prescribing the duties and it may 
even set emission reduction limits for entities. ${ }^{150}$ The regulations under the CCA have not been developed and consequently, the EMCA regulations on air quality and emissions standards could apply. ${ }^{151}$ The Environmental Management and Coordination (Air Quality) Regulations ${ }^{152}$ set emissions standards and prohibit owners or occupiers of facilities from causing emission of air pollutants in excess of the prescribed limits. ${ }^{153}$ They are also required to install air pollution control technologies to mitigate GHGs and monitor emissions. ${ }^{154}$ Thus, entities that emit beyond the prescribed limit or fail to install monitoring and mitigation technologies (or report) could be found to be in violation of the right to a clean and healthy environment.

Regarding government entities, the CCA now requires public bodies to mainstream climate change responses in their planning and decision-making and build resilience and enhance adaptive capacity. ${ }^{155}$ It can be argued that climate change forms part of material considerations to be taken into account in public decision-making and failure to do so can lead to a decision being set aside or a mandatory requirement to consider climate change before decisions can be implemented. ${ }^{156}$ For example, where climate change considerations are not taken into account in the EIA process, then any person may challenge the process, as was the case in the Lamu Coal Power case. ${ }^{157}$

A significant aspect of the Lamu Coal Power decision regarding causation was the NET's application of the precautionary principle. It pointed out that whereas the eventual effects of the project on climate change was unknown, the precautionary principle behoves the NET to reject it. ${ }^{158}$ The provisions on climate change within the Environmental and Social Impact Assessment (ESIA) report were incomplete and inadequate. ${ }^{159}$ Two important aspects can be seen in this case that fit within the trend in environmental cases. Firstly, the insufficient information on the project's impact on climate change led the NET to revoke the licence. Secondly, the non-compliance with CCA, particularly failure to consider climate change issues, contributed to the revocation of the licence. The Respondents attempted to justify the noncompliance by arguing that the CCA was enacted during the EIA process. This did not convince the NET and consequently, it applied the precautionary principle in reversing the approval.

This approach is not peculiar to the NET's decision but, as explained above, courts in Kenya gener- ally take a precautionary approach to environmental protection matters. The precautionary principle requires decision-makers to ensure that a substance or activity posing a threat to human health or the environment is prevented from adversely causing harm. ${ }^{160}$ This was the case in Rodgers Muema where the court noted that since a proper environmental assessment was not conducted, the effects of such mining activities could not be assessed and consequently issued an injunction to restrain the defendant from mining. ${ }^{161}$ In Sam Odera, the court faulted the environmental authority for failing to adopt the precautionary principle when approving a project, noting that the principle should guide all decision-makers in environmental issues. ${ }^{162}$ Furthermore, the environmental courts, which are mandated to determine climate cases under section 23 of the CCA, are to be guided by the precautionary principle when exercising jurisdiction. ${ }^{163}$

150 ibid 6, 15-16.

151 Furthermore, Section 3(3) of the CCA provides that the duties in the Act are in addition to those duties conferred by any other law.

152 Legal Notice No. 34 of 2014 (Air Quality Regulations).

153 ibid 14(1)(b) and 15. The Second Schedule includes GHGs as priority air pollutants subject to the regulations.

154 ibid 16.

155 Climate Change Act s 2.

156 See Lamu Coal Power (n 117) para 138 and the decision of the South African High Court in EarthLife Africa Johannesburg $v$ Minister of Environmental Affairs and Others (65662/16) [2017] ZAGPPHC 58; [2017] 2 All SA 519 (GP). Drawing from jurisprudence in other judicial review cases in Kenya, courts take the view that where public bodies fail to consider material considerations and requirements provided in law, including environmental principles, then the court can review and set aside the decision of the public body. In Republic vs Kenya Forest Service exparte Clement Kariuki \& 2 Others [2013] High Court of Kenya Judicial Review Case 285 of 2012, 2013 eKLR, the court quashed the decision of Kenya Forest Service for failure to consider the statutory requirements on public participation and forest management. In Sam Odera and 3 Others vs National Environmental and Management Authority \& Another [2006] High Court of Kenya Misc. Civil Appl 400 of 2006, 2006 eKLR, the decision of the environmental authority was set aside for failure take material considerations into account. See also Omuko-Jung (n 16) 399-400.

157 NET Appeal No 196 of 2016 [2019] eKLR.

158 ibid 138-139.

159 ibid 139

160 See note 70 above.

161 Rodgers Muema (n 62) 9

162 Sam Odera (n 105) 6 .

163 Section 23 (1) of the Climate change Act provides that an application under the provision is to be made in the Environmental and Land Court. Pursuant to Section 3(3) of the Environment and Land Court Act, the court is to be guided by, among others, the precautionary principle in exercising jurisdiction. 
A trend that can also be seen from environmental cases is the courts' acceptance of the general evidence of potential harm as a probative likelihood of damage. As mentioned above, in Ken Kasinga, the court did not require evidence showing that the telecommunication base erected by the defendant actually caused environmental impacts. ${ }^{164}$ Similarly, in African Centre for Rights and Governance (ACRAG) \& 3 Others $v$ Municipal Council of Naivasha, ${ }^{165}$ the court considered the general evidence that a poorly managed dumpsite is likely to contaminate underground water and a lake and pose a health risk through air pollution. The court found that the operation of the challenged waste dumpsite was a violation of the right to a clean and healthy environment. ${ }^{166}$ The court did not require evidence of how the challenged dumpsite actually contributed to environmental degradation. Rather, general acceptance of the likely impact of such a dumpsite was sufficient.

What this means for climate litigation is that courts are likely to accept the general evidence of the contribution of GHGs on global warming and the impacts of climate change thereof as a probative likelihood of damage from the defendant's activities or the government's inaction. This approach shifts the burden of proof to the defendants who are then required to show that their activities (or in case of government, inaction) do not pose a threat of serious or irreversible damage. ${ }^{167}$ This could be useful in adaptation litigation as well, where the burden of proof may shift to the government to show that it has taken sufficient measures to enhance adaptation and protect its citizens against impacts of climate change. ${ }^{168}$ This position can further be premised on Article 70 (3) of the Constitution and section 23 (3) of the CCA, which provide that one does not need to demonstrate injury in enforcing rights relating to climate change.

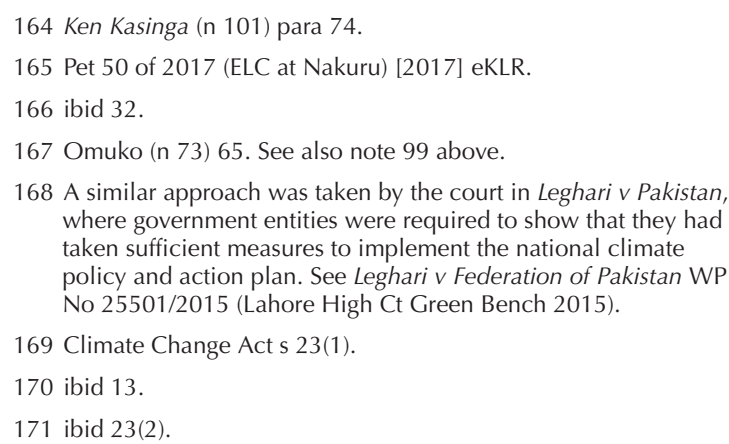

One thing the courts will need to clarify in section 23 of the CCA is what amounts to adversely affecting efforts towards mitigation and adaptation. ${ }^{169}$ Does the provision limit cases to the mitigation and adaptation efforts contained in the country's Nationally Determined Contributions (NDC) or a national climate policy framework? Does the applicant have to show that the alleged actions fall outside the country's mitigation and adaptation plans? It is submitted that rather than being restrictive, the provision is wide and relates to climate change-related obligations arising from the CCA and any other law, including the Constitution. In fact, the country's adaptation and mitigation plans in the NDC or national climate policy could be challenged under this provision if it does not comply with the CCA or Constitution. An example could be that if the national plan does not address all sectors of the economy, is not informed by scientific knowledge, or does not consider marginalised and disadvantaged communities, ${ }^{170}$ then the plan could be challenged under section 23 of the CCA.

Secondly, the orders that can be granted by a court under section 23(2) of the CCA suggest that the provision was not intended to be restrictive or limited to a national climate change plan. For an application under the provision, the court can grant orders to 'a) prevent, stop or discontinue an act or omission that is harmful to the environment; (b) compel a public officer to take measures to prevent or discontinue an act or omission that is harmful to the environment; or c) [pay] compensation to a victim for a violation relating to climate change duties. ${ }^{171}$ The statute gives applicants a clear basis to challenge approval of a project or related activities that are harmful to the environment or violate climate change duties. Considering the precautionary approach, the onus may be placed on the defendant to show that they are emitting within the legally prescribed limits or that they have complied with their climate change duties. For government approval, the entity may have to show whether and how they considered climate change mitigation and adaptation. This could include whether they have considered the project's contribution to climate change or whether the climate risk and vulnerability of public infrastructure projects have been assessed or considered.

As pointed out above, depending on the nature of the proceedings, the court can grant remedies to prevent or discontinue the challenged act, to compel a 
public office to take measures to prevent or discontinue the act or even award compensation. ${ }^{172}$ The relief of compensation raises some questions, especially when one does not have to demonstrate an injury or loss - what would be the basis for compensation, and how would it be assessed? The lack of rules or guidelines on compensation for environmental rights violations has resulted in conflicting jurisprudence on when and how much compensation is due. In some cases, the courts have granted compensation simply in recognition that the petitioner's right to a clean and healthy environment has been infringed. ${ }^{173}$ In other cases, petitioners have been denied damages because they had not shown any loss suffered because of the violation. ${ }^{174}$ It is also unclear what factors the court considers in determining the amount of compensation. In Ken Kasinga, the court awarded an equivalent of about 100 USD, while in Michael Kibui, the court ordered the respondent to pay each petitioner an equivalent of 300 USD. ${ }^{175}$ The courts in both instances did not explain how they reached the amounts. A claimant in a climate compensatory suit is likely to be caught up in this ambiguity, and it may therefore still be useful to provide evidence of injuries or losses arising from climate change impacts, and as far as possible enumerate the extent of those injuries or losses.

Finally, despite the potential for environmental and climate challenges to be brought under Kenyan law, there are no identified instances of climate litigation in Kenya, except the NET's decision in Lamu Coal Power. Climate litigation is a fairly new concept even by global standards. For this reason, countries like Kenya are yet to build the strong legal and scientific expertise on climate change that would support this kind of litigation. Cases that would otherwise be canvassed as climate change litigation are litigated as other issues, sometimes without recognition or mention of the climate change aspect that could exist. The lack of climate litigation has also been attributed to low awareness of climate change issues and a lack of understanding of the government's role in mitigation and adaptation. ${ }^{176}$ While recent studies show an increase in public awareness, ${ }^{177}$ this has been relatively low in previous years, leading to little demand for climate action from both government and private entities. ${ }^{178}$

It may be worth noting that climate litigation in Kenya may be more appropriate for enhancing adaptation and addressing loss and damage as opposed to mitigation, considering the country's low contribution to global emissions, the vulnerability of its population to climate change and its need for development. Indeed, the CCA places both mitigation and adaptation duties on the government, including the duty to develop strategies to enhance adaptive capacity. ${ }^{179}$ This does not however mean that government entities or even corporations should get free passes whenever they fail to comply with legally prescribed climate change mitigation obligations, as this would undermine the rule of law. Litigation targeting mitigation may also still be necessary to ensure that the country is not locked into a carbon-intensive pathway, which could be costly to reverse in future. ${ }^{180}$

\section{Conclusion}

Kenya has undergone changes in public interest environmental litigation from the point where locus standi requirements resulted in a denial of access to courts to the current position where anyone can approach a court for environmental protection without the need to show an injury or loss. The current position presents significant potential and legal opportunities for climate change litigation. Kenyan law creates direct, justiciable rights which do not require

\footnotetext{
172 ibid; Constitution of Kenya art. 70(2).

173 Ken Kasinga (n 101) para 85. In Ken Kasing'a where the court granted the petitioner general damages in recognition that his rights were duly infringed despite the petitioner not showing any specific injury as a result of the violation. Similarly, in Michael Kibui, the court granted the petitioners compensation for breach of their right to clean and healthy environment. There was no evidence of any injury as a result of the breach. Michael Kibui \& 2 others (suing on their own behalf as well as on behalf of the inhabitants of Mwamba Village of Uasin Gishu County) v Impressa Construzioni Giuseppe Maltauro SPA \& 2 others Pet 1 of 2012 (ELC at Eldoret) [2019] eKLR [63]

174 Moffat Kamau (n 99) para 102. Also in Martin Osano Rabera \& another v Municipal Council of Nakuru \& 2 others Pet 53 of 2012 (ELA at Nakuru) [2018] eKLR [79], the court declined to grant compensation because no submissions were made on the nature and quantum of such compensation. This finding is however different from other cases such as Ken Kasinga ( $\mathrm{n}$ 101) where compensation was granted despite no submissions being made on the quantum.

175 Ken Kasinga (n 101) para 76; Michael Kibui (n 169) para 63.

176 See Omuko-Jung (n 16) 402-405.

177 See footnote 10 above.

178 Omuko-Jung (n 16) 404.

179 Climate Change Act s 9(8) and13(3).

180 See Anyango and Odaga (n 17) 129, for a discussion on the need to ensure African countries are not locked into a carbon intensive development pathway.
} 
proof of injury under its climate change legislation, environmental legislation and the Constitution. The fact that there is no need to demonstrate an injury does away with the causation requirement at the $l_{0}$ cus standi stage.

For the trial stage, the requirement not to show injury has created a liability route that allows litigants to avoid the restrictive causation requirements. For instance, the mere non-compliance with statutory/regulatory obligations would amount to a violation of the right to a clean and healthy environment. The claimant is not required to show that such noncompliance contributed to the occurrence of an event which caused or is likely to cause them harm. The other way litigants can avoid the restrictive causation requirement is through the application of the precautionary principle. The precautionary approach taken by courts leads to the conclusion that the courts are likely to accept the general evidence of the contribution of GHGs on global warming and the impacts thereof as a probative likelihood of damage from the defendant's emitting activities or government inaction. This then shifts the burden of proof to the defendants to show that their activities or inaction do not pose a threat of serious or irreversible damage. Consequently, the Kenyan legal system, with its liberalised approach to locus standi and causation, opens the door for public interest-based climate litigation and could make Kenya a potential hotspot for enforcing rights relating to climate change. 